\title{
Peran Pondok Pesantren Syafa'atu Thulab dalam Melestarikan Tradisi Puasa Dalail Khairat di Kabupaten Ogan Ilir
}

\author{
Fitriah \\ Fakultas Adab dan Humaniora UIN Raden Fatah Palembang \\ email : fitriah_uin@radenfatah.ac.id
}

\begin{abstract}
Abstrak
Artikel ini bermaksud memberikan gambaran tentang Eksistensi tradisi Puasa Dalail Khairat serta peran Pondok Pesantren Syafa'atu Thulab dalam melestarikan tradisi Syafa'atu Thulab di Kabupaten Ogan Ilir. Dalam mengumpulkan data, penelitian ini menggunakan metode observasi, interview dan Dokumentasi, Dalam melaksanakan analisis ini peneliti menggunakan reduksi data, display data dan penarikan kesimpulan. Penulis memperoleh fakta bahwa Pondok Pesantren Syafa'atu Thulab merupakan salah satu Pondok Pesantren salafiyah yang masih mempertahankan tradisi-tradisi kepesantrenan yang berbasis kitab kuning. Salah satu kitab yang fenomenal karena menjadi bacaan dan wirid bagi pengamal puasa dahr (puasa tahunan) yakni Kitab Dalail Khairat karangan Syaikh Sulaiman al-Jazuli. Sehingga puasanya sendiri disebut puasa Dalail Khairat. Pelaksanaan Puasa Dalail Khairat di Pondok Pesantren Syafa'atu Thulab sudah ada sejak Pondok Pesantren ini didirikan. Kegiatan Ijazah Kubro pada 7 Syuro setiap tahunnya adalah bagian upaya Pesantren melestarikan Tradisi Puasa Dalail Khairat ini, dan tercatat bahwa peserta pengamal puasa di Pesantren ini merupakan pengamal terbanyak se-Indonesia. Eksistensi tradisi puasa Dalail Khairat masih bisa dijumpai di Pondok Pesantren Syafa'atu Thulab. Pondok Pesantren Syafa'atu Thulab merupakan pesantren satu-satunya di Kabupaten Ogan Ilir yang melestarikan tradisi puasa ini. Pengamal puasanya ini tidak hanya berasal dari santri pesantren, namun juga masyarakat desa dan luar daerah Kabupaten Ogan Ilir, seperti Kota Prabumulih, Banyuasin, Musi Banyuasin dan lainnya. Sehingga tak heran, penganut dan pengamal puasa ini makin bertambah setiap tahunnya.
\end{abstract}

Kata kunci: tradisi, puasa dala'il khairat, pondok pesantren

\begin{abstract}
This article intends to provide an overview of the existence of the Dalail Khairat fasting tradition and the role of the Syafa'atu Thulab Islamic Boarding School in preserving the Syafa'atu Thulab tradition in Ogan Ilir Regency. In collecting data, this research uses observation, interview and documentation methods. In carrying out this analysis the researcher uses data reduction, data display and conclusion. The author accepts the fact that the Syafa'atu Thulab Islamic Boarding School is one of the Salafiyah Islamic Boarding Schools which still maintains the pesantrenan traditions based on the yellow book. One of the phenomenal books because it is a reading and wirid for practitioners of the dahr (annual fast) is the Dalail Khairat Book written by Shaykh Sulaiman al-Jazuli. So that the fast itself is called the Dalail Khairat fast. The implementation of the Dalail Khairat Fasting at the Syafa'atu Thulab Islamic Boarding School has existed since the Islamic Boarding School was founded. The activity of Ijazah Kubro at 7 Shuro each year is part of the pesantren's efforts to preserve the Dalail Khairat Fasting Tradition, and it is noted that the fasting participants at this Islamic boarding school are the most practicing practitioners in Indonesia. The existence of the Dalail Khairat fasting tradition can still be found at the Syafa'atu Thulab Islamic Boarding School. Pondok Pesantren Syafa'atu Thulab is the only pesantren in Ogan Ilir Regency that preserves this fasting tradition. Practitioners of this fast do not only come from pesantren students, but also villagers and outside the Ogan Ilir Regency, such as Prabumulih City, Banyuasin, Musi Banyuasin and others. So it's no wonder, the followers and practitioners of this fast are increasing every year.
\end{abstract}

Keywords: Tradition, The Dalail Khairat fast, Islamic boarding school 


\section{A. PENDAhULUAN}

Secara Historis, pondok pesantren sebagai lembaga pendidikan dan penyebaran ajaran Islam, tumbuh dan berkembang sejak awal masuknya Islam ke-Nusantara. Lembaga pesantren sebenarnya telah tumbuh jauh sebelum Islam masuk ke-Nusantara. Lembaga pesantren pada awalnya merupakan tempat mendalami ilmu-ilmu agama Hindu dan Budha. Bedanya pondok pesantren Islam dikunjungi berbagai lapisan masyarakat, sedangkan pesantren yang didirikan oleh agama Hindu dan Budha hanya dikhususkan dan dikunjungi oleh anak-anak dari golongangolongan tertentu saja. Seiring perjalanan waktu, pondok pesantren tidak tumbuh begitu saja, melainkan mengalami perkembangan sedikit demi sedikit. Jelaslah bahwa pondok pesantren bukan hanya sekedar mampu bertahan, namun dengan penyesuaian, akomodasi, dan konsensi yang dilakukan oleh lembaga ini, pada gilirannya pondok pesantren mampu mengembangkan dirinya dan bahkan menempatkan dirinya pada posisi penting.

Tradisi pesantren bernafaskan sufistik, ubudiyah dan ibadah fardhu dilengkapi dengan shalat-shalat sunnah, dzikir, wirid dan ratib. Banyak kiyai yang berafiliasi dengan tarekat dan mengajarkan kepada pengikutnya ibadah dan amalan sufistik yang khas. Dengan kata lain, Pondok pesantren tidak hanya memberikan pendidikan formal berbasis kurikulum yang memang diperlukan untuk menunjang masa depan para santri dalam dunia akademik, akan tetapi pondok pesantren juga memberikan wadah pendidikan yang bersifat khusus seperti amalan-amalan khusus untuk lebih mendekatkan diri kepada Tuhan. Sebagaimana yang telah diterapkan di Pondok Pesantren Syafa'atut Thulab yang berada di Desa Bakung Kecamatan Indralaya Utara, Kabupaten Ogan Ilir Sumatera Selatan, yang didirikan oleh K.H. M. Qusyairi Abror, S.IF pada 2008 silam.

Selain pendidikan formal yang di landasi oleh kurikulum pemerintah, Pondok Pesantren Syafa'atut Thulab ini juga menerapkan suatu peramalan khusus yang telah berjalan beberapa lamanya yang dikenal dengan Dala'il Khairat. Dala'il Khairat merupakan antologi rumusanrumusan shalawat nabi yang diamalkan sebagai praktek beragama keseharian. Substansi amalan Dala'il Khairat adalah memberikan bimbingan seorang pengamal mencapai sebuah kualitas yang lebih baik dalam rangka mendekatkan diri kepada Tuhan, hal ini dapat disebut sebagai bentuk aktifitas tasawuf atau sebuah pengalaman keberagamaan bagi para pengamalnya.

Selanjutnya, Kitab Dalai'il Khairat sendiri disusun oleh Syaikh Sulaiman al-Jazuli dari Maroko. Jika dilihat dari sanad pengamalan Dala'ilul Khairat terutama di tanah Jawa, rata-rata sanadnya akan bertemu pada Syekh Muhammad Mahfudz At-Tarmasi Pacitan (w. 1920 M). Sebagaimana dijelaskan oleh Syekh Muhammad Mahfudz At-Tarmasi pada Kitab Kifayatul 
Mustafid, "Kitab Dala'ilul Khairat kami dapatkan dari Syekh Ahmad Muhammad bin Ahmad Ridwan al-Madani, dari Ali bin Yusuf Al-Madani, dari Sayyid Muhammad bin Ahmad AlMadghari, dari Muhammad bin Ahmad bin Ahmad Al-Matsani, dari Ahmad bin Al-Haaj, dari Abdul Qadir Al-Faasi (w. 1091 H), dari Ahmad Al-Maqqari (w. 1041 H), dari Ahmad bin Abu Al-Abbas Ash-Shama'i, dari Ahmad bin Musa As-Samlali, dari Al-Quthb Abdullah Al-Ghazali AlMarakisyi, dari Abdul Aziz At-Tabba' (w. 914 H), dari pengarang kitab ini, Imam Muhammad bin Sulaiman Al-Jazuli (w. 870 H).”

Di Jawa Tengah ada Pondok Pesantren Darul Falah Kudus, diijazahkan oleh KH. Ahmad Badawi Basyir lewat jalur KH. Ahmad Basyir Jekulo (w.2014 M) mendapat ijazah dari Kiai Muhammadun Pondowan, dari Syekh Yasin Jekulo (w. 1953 M) pengasuh Pondok AlQoumaniyah, dari Syekh Muhammad Amir bin Idris bin Ahmad Salih Al-Syarbuni Pekalongan, dari Syekh Muhammad Mahfudz At-Tarmasi.

Wirid Dala'ilul Khairat yang dijadikan tirakat di pondok tersebut dihimpun dalam sebuah kitab karangan Mbah Basyir (KH. Ahmad Basyir Jekulo) yang berjudul Nailul Masarrat. ${ }^{1}$ Kitab ini dikarang sebagai bentuk mengharap limpahan berkah dan penghormatan yang kemudian diminta-kan tashih kepada tiga ulama pentashih yang memiliki keilmuan yang mulia. Ketiganya berasal dari Pekalongan. Beliau bertiga adalah KH. Idris bin Amir Simbang Kulon (Putra Syekh Muhammad Amir bin Idris Sekretaris Pribadi Syekh Mahfudz At-Tarmasi Ketika bermukim di Makkah), Al-Habib Ahmad bin Ali bin Ahmad al-Atthas Sapuro, dan Maulana Al-Habib Muhammad Luthfi bin Ali bin Hasyim bin Yahya (Beliau adalah Mursyid Thariqah Syadziliyah).

Demikian juga di daerah Kabupaten Ogan Ilir, di desa Bakung, eksistensi Tradisi pengamalan Dala'il Khairat dapat dijumpai disana. Menurut Pendiri Pesantren Syafa'atut Thulab sekaligus Pembimbing pelaksanaan puasa Dala'il Khairat, tercatat ada seribuan orang yang telah melaksanakan puasa tersebut, yang terdiri dari santri mukim dan jama'ah/santri non mukim yang tersebar di Kabupaten Ogan Ilir.

Tradisi puasa yang tidak biasa dengan peminat yang cukup banyak ini, tentunya menjadi suatu fenomena yang menarik untuk diteliti, mengingat tradisi ini (menurut hemat penulis) merupakan satu-satunya yang dipraktikkan di wilayah Kab. Ogan Ilir Provinsi Sumatera Selatan.

\footnotetext{
${ }^{1}$ Ahmad Tajuddin Arafat, "Tiga Ulama Pentashih Kitab Nailul Masarrat," Pesantren.Id, July 2020, accessed September 2, 2020, https://pesantren.id/tiga-ulama-pentashih-kitab-nailul-masarrat-karya-kh-ahmadbasyir-kudus-5325/.
} 


\section{B. TINJAUAN PUSTAKA}

Terkait dengan Penelitian ini, sebelumnya juga pernah ada yang memberikan ulasan yang senada dengan kajian dalam tulisan ini. Diantaranya:

Jurnal yang berjudul, Pendidikan Karakter di Pesantren Darul Falah Kecamatan Jekulo Kabupaten Kudus, yang ditulis oleh Muhammad Mujibur Rohman, Dewi Liesnoor Setyowati, Wasino $^{2}$ Jurnal ini mengkaji tentang pendidikan karakter di pesantren Darul Falah yang dilatar belakangi urgensi pesantren sebagai tempat pengembangan pendidikan karakter.

Selanjunya penelitian Masturin ${ }^{3}$ yang berjudul Perilaku Sosial Budaya Pengikut Tarekat Dala'ilul Khairat Pada Pondok Pesantren Darul Falah Jekulo Kudus dalam jurnal Kuriositas, Edisi VIII, Vol. 1, Juni 2015, dalam penelitian ini Masturin mengamati bagaimana prilaku sosial para pengikut Tarekat Dala'il Khairat dalam menjalankan kehidupan sehari-hari.

Terakhir, Tulisan yang berjudul Organisasi Sosial Dala'il Khairat (Studi Pengamal Dala'il Khairat K.H Ahmad Basyir Kudus), Penulis ini menemukan spirit Dala'il Khairat terhadap etos kerja dan peningkatan ekonomi santri. Selain itu, kajian ini juga berupaya melihat proses-proses yang telah dijalani para pengamal dalam mengembangkan usaha demi meraih kesuksesan di bidang ekonomi.

Dari beberapa tulisan di atas, beberapa bagian isi memang sudah ada yang mengkaji lebih detail berkenaan dengan kajian yang diangkat oleh penulis. Namun, kajian penulis yang memfokuskan pada perkembangan Dala'il Khairat yang ada di Kabupaten Ogan Ilir dengan Persfektif Sosial belum ada yang mengimplementasikan kedalam tulisan ilmiah.

\section{METODE PENELITIAN}

\section{Jenis Penelitian}

Penelitian ini adalah penelitian lapangan (Field Reasearch) yakni melakukan penelusuran secara langsung ke lapangan atau objek penelitian untuk menggali informasi terkait dengan tradisi puasa Dala'il khairat, dengan menggunakan metode Deskriptif Kualitatif.

\section{Teknik Pengumpulan Data}

Dalam tahap ini dilakukan pengumpulan data yang sesuai dengan objek penelitian. Adapun tahapannya sebagai berikut:

\footnotetext{
${ }^{2}$ Rohman, Muhammad Mujibur, and Dewi Liesnoor Setyowati, "Pendidikan Karakter Di Pesantren Darul Falah Kecamatan Jekulo Kabupaten Kudus,” Journal of Education Social Studies Vol. 1, No. 2 (2012).

${ }^{3}$ Masturin, "Perilaku Sosial Budaya Pengikut Tarekat Dalailul Khairat Pada Pondok Pesantren Darul Falah Jekulo Kudus," Kuriositas: Media Komunikasi Sosial dan Keagamaan Vol. 8, No. 1 (2015), http://ejurnal.stainparepare.ac.id/index.php/kuriositas/article/view/141.
} 


\section{a. Observasi (Pengamatan)}

Peneliti melakukan pengamatan langsung di lokasi Pondok Pesantren Syafa'atut Thulab Desa Bakung Kabupaten Ogan Ilir Provinsi Sumatera Selatan.

\section{b. Interview (Wawancara)}

Dalam melakukan wawancara, peneliti menggunakan wawancara tidak terstruktur. Wawancara ini lebih sesuai digunakan untuk penelitian kualitatif, sebab jenis wawancara ini memberikan peluang kepada peneliti untuk mengembangkan pertanyaan-pertanyaan dalam wawancara. Adapun pihak-pihak yang menjadi informan dalam penelitian ini antara lain adalah pengasuh dan pengurus Pondok Pesantren, Santri, Jemaah yang terlibat dalam tradisi puasa Dala'il Khairat serta tokoh Agama yang mengetahui tentang tradisi puasa Dala'il khairat yang ada di Pondok Pesantren Syafa'atut Thulab.

\section{c. Dokumentasi}

Metode ini digunakan untuk memperoleh dan mengumpulkan data tertulis baik bersifat teoritik maupun factual yang diambil dari berbagai macam data diantaranya buku, foto, artikel, video, naskah, skripsi dan catatan ataupun data lain yang dapat menyempurnakan hasil penelitian serta hubungannya dengan peran Pondok Pesantren serta tradisi Puasa Dala'il Khairat tersebut.

\section{Teknik Pengolahan/Analisis Data}

Untuk melakukan analisis terhadap hasil data yang didapatkan baik berupa hasil observasi, wawancara, dan dokumentasi. peneliti melakukan pengolahan data dengan beberapa tahapan antara lain :

a. Reduksi data

Dalam tahap ini penulis melakukan pengumpulan dan pemilihan data yang didapatkan di lapangan. Data akan dipilah dan diseleksi sesuai dengan kebutuhan penelitian. Pada tahap reduksi peneliti menyaring representasi makna ataupun informasi yang didapat sesuai dengan lingkup permasalahan yang digarap.

b. Display data

Display data dapat juga dikatakan sebagai klasifikasi data. Berbagai data penelitian dengan sifatnya yang juga beraneka ragam dikecilkan berdasarkan beberapa persamaan atau perbedaan

c. Penarikan kesimpulan

Pada tahap ini penulis melakukan analisis terhadap data sehingga dapat ditarik 
kesimpulan dari hasil penelitian yang telah dilakukan.

\section{HASIL DAN PEMBAHASAN}

\section{Profil Lokasi Penelitian}

Pondok Pesantren Syafa'atut Thulab berada di tengah lingkungan penduduk Desa Bakung, yang secara geografis berbatasan dengan dua kabupaten, yaitu Kabupaten Ogan Ilir dan Kabupaten Muara Enim. Desa Bakung sendiri termasuk dalam salah satu wilayah kecamatan Indralaya Utara, kabupaten Ogan Ilir, Provinsi Sumatera Selatan. Desa Bakung terdiri dari tiga dusun dengan luas wilayah lebih kurang $6000 \mathrm{Ha}$.

Pondok pesantren Syafa'atut Thulab didirikan oleh Ky. M. Qusyairi Abror, S.IF, tepatnya pada tanggal 17 April 2008. Beliau adalah putra dari Bapak M. Abror almarhum dan Ibu Siti Pariyah dari Banyu Wangi Jawa Timur. Sejak kecil beliau mempunyai sifat kemandirian yang kukuh untuk memperjuangkan Islam, Arif serta mempunyai jiwa sosial yang tinggi. Setelah menganjak dewasa, beliau melanjutkan Tholabul Ilminya kepada al-Mukarrom Asy-Syaikh KH. Imam Barizi, S.IF, Pengasuh Pondok pesantren Syafa'atut Thulab Desa Tugu Jaya Kecamatan Lempuing Kabupaten Ogan Komering Ilir Sumatera Selatan, Beliau alumni Pondok Pesantren Darusssalam Blok Agung Banyu Wangi Jawa Timur. Selama di pesantren terpancarlah sifat-sifat kepemimpinan dan kearifan beliau. Selain itu, beliau dari kecil juga diberi keahlian dalam bidang pengobatan segala macam penyakit baik dzohir maupun bathin. Sehingga sampai sekarang masih banyak warga sekitar, atau luar daerah bahkan lain provinsi yang dating dan mengenal beliau. ${ }^{4}$

Setelah menyelesaikan studinya beliau menikah dengan seorang wanita yang bernama Nyai Siti Marfu'ah santri dari Almukarrom KH. Masluk Arrodly Nurba, pengasuh Pondok Pesantren Nurul Ulum Desa Muara Burnai II Kecamatan Lempuing Kabupaten Ogan Komering Ilir Sumatera Selatan. Setelah beberapa bulan dari pernikahannya Beliau merasa sangat terpanggil untuk menyebarkan dan mengembangkan ajaran Agama Islam, untuk membendung derasnya arus globalisasi yang dapat mengancam nilai-nilai agama/moral dan menyelamatkan generasi muda Islam dari pengaruh negative Globalisasi serta menamkan aqidah islam, maka beliau mendirikan Lembaga yang diberi nama : Yayasan Pendidikan Pondok Pesantren Syafa'atut Thulab.

Pondok pesantren Syafa'atut Thulab didirikan oleh Ky. M. Qusyairi Abror, S.IF, tepatnya

${ }^{4}$ M. Qusyairi Abror, “Pimpinan Pondok Pesantren Syafa'atu Thulab,” June 10, 2020. 
pada tanggal 17 April 2008. Pendirian lembaga Yayasan Pendidikan Pondok Pesantren Syafa'atut Thulab ini, didasarkan pada sifat jihadiyah Beliau yang merasa sangat terpanggil untuk menyebarkan dan mengembangkan ajaran Agama Islam, untuk membendung derasnya arus globalisasi yang dapat mengancam nilai-nilai agama/moral dan menyelamatkan generasi muda Islam dari pengaruh negative Globalisasi serta menanamkan aqidah Islam. Yayasan Pendidikan Pondok Pesantren Syafa'atut Thulab hadir untuk memberi respon masyarakat dan menjadi benteng dampak negative Globalisasi (Dekadensi Moral, Kenakalan Remaja, Minuman Keras, Kriminalitas, Kerusakan Akhlak, dan Tindakan Maksiat lainnya yang semakin mengkhawatirkan. Pondok Pesantren Syafa'atut Thulab didirikan tepatnya di Jalan Patra Tani Desa Bakung Kecamatan Indralaya Utara Kabupaten Ogan Ilir Sumatera Selatan.

Pada awalnya tahun 2008, Pondok Pesantren ini berada cukup jauh dari pemukiman penduduk dengan kata lain tidak ada tetangga sama sekali, masyarakat jaraknya lebih kurang 2,5 km dari Pondok Pesantren ini. Saat itu, keadaan di sekitar pesantren masih hutan, dan juga kebun karet yang baru di tanam (plasma karet) yang merupakan milik warga Desa Bakung. Kondisi Pondok Pesantren saat itu masih dalam kondisi yang cukup memprihatinkan, tertutama masalah kondisi keagamaan masyarakat. Warga lebih banyak berada dikebun-kebun, dan masyarakat belum terorganisasi dengan baik dalam masalah kemasyarakatan, terlebih dalam hal keagamaan. Sejak berdirinya Pondok Pesantren Syafa'atut Thulab tahun 2008 tersebut, Alhamdulillah, Syiar agama mendapat apresiasi yang sangat baik dari masyarakat Desa Bakung. Dan dengan dukungan masyarakat juga Pondok Pesantren Syafa'atut Thulab dapat mengembangkan dan menyebarluaskan ajaran pendidikan Pondok pesantren Syafa'atut Thulab ini ${ }^{5}$ (Hasil Wawancara dengan Ky. M. Qusyairi Abror, S.IF).

Yayasan Pendidikan Pondok Pesantren Syafa'atut Thulab adalah sebuah Yayasan Pendidikan Islam Sistem Pondok Pesantren yang dikombinasi dengan penggunaan kurikulum Kementerian Agama dan Pendidikan Nasional. Maka dari itu, jenjang pendidikan formal di adakan di pondok pesantren ini mulai dari Madrasah ibtidaiyah, Madrasah Tsanawiyah, hingga Madrasah Aliyah dengan penggunaan Kurikulum pendidikan yang berlaku secara nasional, tanpa mengkesampingan pendidikan non formal pondok pesantren yang telah mentradisi di pondok pesantren lainnnya yang tersebar di seluruh indonesia.

Hal menarik dari Pondok Pesantren Syafa'atut Thulab yang tidak biasa diajarkan dan dipraktikkan di pondok pesantren lain, ialah pengamalan Puasa Dala'il Khairat yang menjadi ciri khas utama Pondok Pesantren Syafa'atut Thulab di bandingkan pesantren yang ada di sumatera 
selatan. Hal ini akan menjadi bahasan tersendiri dalam sub bab selanjutnya.

Tujuan Pendidikan Pondok Pesantren Syafa'atut Thulab ialah Membentuk Insan yang Tafaqquh Fiddin, Beriman dan Bertaqwa (IMTAQ) Berilmu Pengetahuan dan Teknologi (IMTEK) Berakhlakul Karimah, Berjiwa Mandiri yang Siap Membimbing dan Memimpin Ummat serta Penebar Agama Islam Dimanapun Berada.

Adapun Motto Pondok Pesantren Syafa'atut Thulab berbunyi : Pengen Urip Sukses Lan Barokah "Obahno Awakmu, Fikiranmu, Lan Atimu Marang Alloh Swt” (Ingin Hidup Sukses dan Berkah “Ubah Dirimu, Pikiranmu dan Hatimu Hanya Kepada Allah Swt”).

\section{Kurikulum Pondok Pesantren Syafa'atut Thulab}

Terkait mengenai Unit Pendidikan yang ada di Pondok Pesantren Syafa'atut Thulab, menjalankan pendidikan Formal yang menggunakan kurikulum nasional, melalui penyelenggaraaan Sekolah Dasar, Menengah hingga pendidikan atas. Jenjang pendidikan yang ada di Pondok Pesantren Syafa'atut Thulab mulai pada tingkat Madrasah Ibtida'iyyah (MI Setara SD) dengan predikat Akreditasi B, kemudian Madrasah Tsanawiyah (MTs Setara SMP), juga Terakreditasi B dan terakhir tingkat Madrasah Aliyah (MA Setara SMA) juga Terakreditasi B. Hal tersebut menunjukkan bahwa, pondok Pesantren ini tidak hanya menjalankan Tradisi Salaf yang hanya menekankan pada pembelajaran kitab-kitab kuning saja sebagai pengajaran utama, namun juga keikut sertaan pendidikan wajib belajar yang merupakan program wajib pemerintah juga terlaksana dengan baik di Pondok Pesantren Syafa'atut Thulab.

Selain itu, ada juga pendidikan non formal yang menjadi pendidikan wajib bagi para santri yang tidak termasuk dalam kurikulum nasional sebagaimana dijelaskan di atas, seperti RA / TPA Syafa'atut Thulab yang diperuntukkan bagi anak-anak luar pondok yang ingin belajar dan mendalami bacaan Al-Qur'an. Lalu Madrasah, Diniyah (Ula, Wustho, Ulya), Pengajian Kitab Kuning / Kitab-kitab Salaf, Tahfidzul Qur'an, Thoriqoh Qodriyah Wa Naqsabandiyah, dan Puasa / Riadhoh Dala'ilul Khoirot 1 \& 3 Tahun serta Ijazah Kubro setiap Malam Tujuh Suro (yang menjadi pokok bahasan Penelitian ini).

Lebih lanjut ada juga pendidikan Ekstrakurikuler yang bertujuan untuk memberikan bekal keahlian terhadap santri pasca mengenyam pendidikan di Pondok Pesantren Syafa'atut thulab, agar dapat berdaya guna di tengah kehidupan sosial masyarakat, yang meliputi: Pelatihan Pidato dan MC, Pelatihan Tilawatil Qur'an, Musyawarah Kitab Fathul Qorib, Bimbingan jadi Imam Yasin dan Tahlil, Bimbingan Bilal Jum'ah dan Tarawih, Bimbingan Mengurus Jenazah, AlBarzanji \& Istighotsah, Kaligrafi/ Khot, Wagean/Ahad Wage (Surat Waqi'ah dan Manaqib), 
Sulawesan Manaqib Syaikh Abdul Qadir Jailani, Pencak Silat Pagar Nusa, PSTD Elang Putih, Pertanian, Pertukangan, Peternakan, Kursus Menjahit, dan lain-lain.

Kendati tumbuh dan berkembang dimasa kekinian, namun Pondok Pesantren Syafa'atut Thulab tetap mempertahankan eksistensinya sebagai Pondok Salafiyah. Pondok Pesantren Salafiyah adalah Pondok Pesantren yang masih mempertahankan sistem pendidikan khas Pondok pesantren, baik kurikulum maupun metode pendidikannya. Bahan ajar meliputi ilmu-ilmu agama Islam, dengan mempergunakan kitab-kitab klasik berbahasa arab, atau yang kita kenal dengan Kitab Kuning.

\section{Kitab Dala'il Khairat dan Puasa Dala'il Khairat}

Masyarakat Indonesia memiliki banyak tradisi dan budaya yang berasal dari kearifan lokal, yang dipengaruhi oleh ajaran agama, kebiasaan adat istiadat dan aturan nenek moyang. Dalam sejarahnya puasa Dala'il Khairat adalah jenis puasa yang berkembang di masyarakat daerah Kudus, Jawa Tengah, yang kemudian disebarkan oleh para murid-muridnya melalui sanad. Sanad inilah yang merupakan mata rantai pengamalan puasa hingga ke penulis kitab Dala'il khairat, yakni Syaikh Sulaiman al-Jazuli, dan sanad inilah yang diberikan kepada pengamal yang telah menyelesaikan puasa.

Keberadaan puasa Dala'il Khairat masih asing dikalangan umum atau masyarakat di Indonesia, puasa Dala'il Khairat hanya dikenal oleh kalangan pesantren dan oleh para ulama. Sementara itu, orang-orang di kalangan umum yang mendengar pelaksaan puasa Dala'il Khairat akan memiliki persepsi yang negatif, karena ibadah tersebut bersifat paksaan, bahkan banyak orang perpendapat, puasa ini adalah ajaran yang sesat karena tidak adanya referensi hadist nabi Muhammad SAW. Terlepas dari persepsi itu semua, puasa ini masih banyak yang melaksanakannya dengan tujuan mencari keberkahan.

Semua bentuk puasa Dala'il Khairat pada umumnya tergantung pada guru yang mengijazahkan terkait lama waktu dan amalan-amalan pendampingnya. Dala'il Khairat merupakan sebuah kitab karya seorang ulama Maroko, Afrika Utara. Kitab ini sangat masyhur dikalangan pondok pesantren. Nail al-Masarat fi Tashih Dala'il Khairat merupakan kitab yang telah ditashih (pembetulan) oleh KH. Ahmad Basyir. beliau mengatakan bahwa: "Karena saking banyaknya cetakan, terdapat banyak kekeliruan yang akibatnya merubah makna."

Menurut literatur yang peneliti baca, awalnya Dala'il Khairat yakni ketika ulama besar Syekh Sulaiman Al-Jazuli Maroko pergi ke Baitullah, Mekah bersama santrinya. Namun di tengah jalan rombongan kehabisan air. Akhirnya dia menemukan sumur yang dalam namun tidak 
ada gayungnya. Saat itu muncullah anak perempuan penduduk setempat yang meminta Syekh Sulaiman Al-Jazuli untuk membaca selawat kepada Nabi Muhammad. Seketika itu, air yang ada di dalam sumur tersebut tiba-tiba naik. Lalu akibat peristiwa tersebut Syekh Sulaiman Al-Jazuli akhirnya mengarang kitab Dala'il Khairat yang berisi kumpulan salawat kepada Nabi Muhammad. ${ }^{6}$

Puasa Dala'ilul Khairat adalah puasa riyadhah sunnah yang diamalkan dalam waktu beberapa tahun dengan membaca kitab Dala'il Khairat setiap hari, dengan tujuan untuk mencari berkah (Tabarruk) sesuai anjuran Al-Quran sesungguhnya Allah dan malaikat-malaikat-Nya bershalawat kepada Nabi. Wahai orang-orang yang beriman, bershalawatlah kalian dan ucapkanlah salam penghormatan kepada-Nya (Surat Al-Ahzaab ayat 56)". Puasa Dala'il khairat merupakan puasa yang dilaksanakan selama 3 tahun berturut-turut yang dibarengi dengan pembacaan wirid setiap harinya. Wirid yang terdapat dalam Kitab Dala'il Khairat ini berisi beragam sholawat. Sebelum melaksanakan puasa, pelaku puasa ini harus meminta izin terlebih dahulu kepada guru atau yang biasa disebut mujiz. Biasanya dalam sebuah pesantren yang mengamalkan tradisi Dala'il tersebut yang bertindak sebagai Mu'jiz adalah pimpinan Pondok Pesantren.

Praktik puasa ini dilandasi hadis tentang puasa dahr atau puasa tahunan, serta hadis tentang keutamaan berpuasa. Namun dalam praktiknya belum banyak yang memahami landasan ini secara langsung. Namun tidak dapat diketahui bagaimana proses transformasi pengetahuan tersebut hingga praktik puasa dahr dapat digabungkan dengan pengamalan wirid sholawat

\section{Tujuan dan Motivasi Puasa Dala'il Khairat}

Puasa merupakan ibadah rahasia yang sangat ideal dalam membentuk ketaqwaan, dan memang pada hakikatnya ketaqwaan merupakan tujuan utama dari ibadah puasa. Puasa adalah salah satu cara terbaik untuk mengkaderisasi seseorang agar selalu bertaqwa kepada Allah. Karena di dalam puasa terdapat perintah Allah yang harus dilakukan dan laranganNya yang harus dijauhi. Orang yang berpuasa meninggalkan segala larangan Allah hanya karena ingin dekat dengan Allah dan mengharapkan ridha Allah. ${ }^{7}$

Pada dasarnya pelatihan merupakan proses pembiasaan yang akan mempengaruhi keadaan hati dan jiwa seseorang. Sesuatu yang dibiasakan dalam kehidupan sehari-hari akan mempengaruhi dan membekas dalam hati. Semakin lama suatu tindakan atau perilaku

\footnotetext{
${ }^{6}$ Kisbiyanto, Sejarah Pengarang Kitab Dalailul Khairat Syakh Abu Abdillah Muhammad Bin Sulaiman AlJazuli (PP Darul Falah Jekulo Kudus, 2000). n.d., h. 86.

${ }^{7}$ Abd ar-Rahman, Taisir Al-Karim Ar-Rahman Fi Tafsir Kalam al-Mannan,Muassasah Ar-Risalah, Riyadh,
} 
dibiasakan,semakin dalam membekas dalam hati dan pada akhirnya akan menjadi tabiat. Pada tahap berikutnya, tabiat yang terus dihayati akan terbentuk menjadi kepribadian atau akhlak. Kepribadian yang hendak dibentuk adalah taqwa. Seorang yang bertaqwa adalah orang yang menjaga, memelihara, dan mengawasi dirinya sehingga selalu melakukan kebaikan dan menghindari keburukan.

Puasa membiasakan seseorang takut kepada Allah SWT, baik dalam keadaan sendirian atau dengan orang banyak. Sebab, orang yang melakukan puasa tidak ada pengawas yang mengawasi kecuali Tuhannya. hal ini artinya puasa juga dapat melatih kesabaran dari hal yang tidak disukai seperti musibah kematian, sakit, kelaparan dan sebagainya, dan hal-hal yang disenangi misalnya segala kenikmatan duniawi yang disukai oleh hawa nafsu. Sabar dalam hal ini berarti menahan dan mengekang diri dari memperturutkan hawa nafsu.

Puasa juga bertujuan memadamkan Syahwatain, Syahwatain yang dimaksud disini adalah syahwat perut dan syahwat farji artinya keinginan makan, minum dan keinginan untuk bersetubuh. Keduanya merupakan bagian dari sifat madzmumah (tercela). Bahaya yang paling besar adalah orang-orang yang menuruti keinginan perutnya. Seperti contoh Nabi Adam As yang dikeluarkan dari surga karena menuruti keinginannya untuk memakan sesuatu yang dilarang Allah SWT. Syahwat perut ini jika tidak dipadamkan maka akan menjalar ke banyak syahwat yang lain, seperti kesenangan jima, hubb ad-dunya (cinta dunia) sehingga akhirnya muncul sifat takabbur dan riya. Semua ini bisa dipadamkan dengan puasa.

Terkait dengan tujuan dan motivasi dari puasa Dala'il Khairat ini, pada hakikatnya tidak jauh berbeda dengan tujuan dan motivasi dari puasa pada umumnya, yang telah disebutkan di atas. Dengan membiasakan puasa setiap hari, artinya membiasa-kan diri untuk selalu dalam kebaikan baik perkataan, maupun perbuatan. Mengontrol diri untuk takut kepada Allah, sehingga terlatih untuk bisa melakukan perbuatan baik yang dianjurkan dan menahan diri dari perbuatan yang dilarang.

Sesuai dengan janji Allah ketika seseorang telah menjaga dirinya dari hal-hal yang dilarang, maka diharapkan riyadhah puasa ini akan membuka semua hajat yang diharapkan oleh pengamalnya. Sehingga tidak heran, ada berbagai tujuan berbeda dari para pengamal Dala'il Khairat ini selain taqwa ini, antara lain berharap kebaikan untuk duniawi, yang dalam istilah pimpinan pondok pesantren Syafa'atu Thulab menyebutnya dengan istilah "mempuasai jodoh", jodoh calon suami, calon anak, calon mertua, pekerjaan, karir, dan lainnya.

Selain itu, bagi santri sendiri, puasa Dala'il khairat ini, melatih mereka dalam berkonsetrasi

${ }^{8}$ Abror, "Pimpinan Pondok Pesantren Syafa'atu Thulab." 
dalam belajar dan menghapal Alquran dan pelajaran-pelajaran mereka. ${ }^{9}$ Sehingga tak sedikit dari mereka yang melakukan puasa mempunyai prestasi yang lebih unggul dari temannya yang tidak mengamalkan puasa Dala'il Khairat ini.

\section{Pelaksanaan Puasa Dala'il Khairat di Pondok Pesantren Syafa'atu Thulab}

Pelaksanaan puasa dalalil khairat di Pondok Pesantren Syafa'atu Thulab, tidak terlepas dari rentetan kegiatan yang mengiringinya di antaranya Ijazah Kubro.

Pengertian Ijazah menurut Kamus Besar Bahasa Indonesia (KBBI) mempunyai dua arti yakni surat tanda tamat belajar; dan izin yang diberikan oleh guru kepada muridnya untuk mengajar-kan ilmu yang diperoleh si murid dari gurunya. ${ }^{10}$ Pada pengertian pertama Ijazah dimaksudkan sebagai tanda atau bukti resmi tentang orang, santri, siswa atau mahasiswa yang dibuktikan dalam sebuah sertifikat atau dokumen yang diberikan oleh suatu intansi setelah menyelasaikan studinya.

Pada pengertian kedua, Ijazah diartikan sebagai suatu bentuk perizinan dari seorang kyai kepada para santri untuk mengamalkan satu amalan yang bermanfaat yang berkenaan dengan masalah-masalah duniawi atau masalah-masalah ukhrowiyah dengan tujuan untuk mendapatkan atsar, manfaat, dan barokah yang luar biasa manakala dilaksanakan sesuai dengan petunjuk.

Sedangkan kata kubro dalam Bahasa Arab diartikan besar. Dalam tradisi pesantren salafiyah, istilah Ijazah kubro ini biasa digunakan untuk proses pemberian perizinan oleh beberapa kyai kepada santri untuk mengamalkan wirid-wirid atau amalan-amalan, biasanya proses ini diselenggarakan dengan mengundang banyak peserta dan menggunakan tempat yang luas.

Pada Pondok Pesantren Syafa'atu Thulab, ijazah kubro ini merupakan bagian dari rangkaian praktik puasa Dala'il khairat. Kegiatan ini biasanya dilaksanakan pada tanggal 7 Syuro atau tanggal 7 pada bulan Muharram setiap tahunnya. Pada tanggal 1 syuro atau 1 Muharram, para pengamal puasa biasanya sudah memulai puasanya.

Adapun tata cara pertama untuk berpuasa, para santri atau masyarakat yang ingin berpuasa terlebih dahulu mendaftarkan diri pada seksi/petugas yang telah ditunjuk oleh Pimpinan Pesantren. Proses pendaftaran tidak lama hanya menyebutkan nama, orang tua dan asal dari mana. Selanjutnya pengamal mulai berniat dan mulai melakukan puasa.

Kemuadian pada tanggal 7 Syuronya, para pengamal diundang hadir untuk mengambil ijazah wirid atau bacaan yang harus dibaca selagi puasa, dan wirid yang dibaca oleh pengamal

9 “Santri Pengamal Puasa Dalail Khairat," June 11, 2020.

10 “Kamus Besar Bahasa Indonesia,” n.d., accessed July 20, 2020, https://kbbi.web.id/ijazah. 
Puasa Dala'il Khairat, adalah Kitab Dala'il Khairat yang telah disebutkan di atas. Mengenai teknik bacaannya, Pesantren punya metode sendiri yang disampaikan pada malam pengijazahan tersebut. Hal ini dikarenakan dalam kitab Dala'il khairat tersebut tersebut tidak dicantumkan bagaimana cara membacanya atau mengamalkannya.

Kegiatan ijazah kubro ini biasanya dihadiri oleh berbagai lapisan masyarakat, mulai dari pejabat pemerintah, tokoh masyarakat, tokoh agama, organisasi keagamaan, masyarakat sekitar pesantren serta santri dan wali santri pondok pesantren Syafa'atu Thulab.

Acara Ijazah Kubro ini biasanya dilaksanakan pada malam hari selesai Shalat Isya'. Untuk menampung banyaknya peserta dan undangan, kegiatan tersebut biasanya diadakan di Lapangan Pondok Pesantren Syafa'atu Thulab. Dengan mendirikan sebuah panggung yang berhias dan dipasang badrop serta bebrapa unit tenda yang digelar tikar dibawahnya.

Kegiatan biasanya dimulai dengan acara sambutan-sambutan dari pejabat pemerintahan yang diundang serta dilanjutkan dengan sambutan dari pendiri sekaligus mudir pondok pesantren. Setelah sambutan, kegiatan dilanjutkan dengan penyerahan piagam bagi para pengamal puasa yang telah menyelesaikan puasanya. Piagam yang diberikan berbeda-beda tingkatan sesuai dengan lama puasa yang dijalankan. Mulai dari satu tahun, dua tahun, tiga tahun, lima tahun dan tujuh tahun. Begitu juga dengan puasa yang dilakukan, tidak hanya puasa Dala'il khairat, namun ada juga yang melakukan puasa Daud, Puasa Mutih, dan Puasa Ngerawot. Adapun tujuan dari pemberian piagam ini dimaksudkan untuk memberikan apresiasi dan motivasi bagi para pengamal puasa.

Setelah penyerahan piagam, kegiatan dilanjutkan dengan pengijazahan kitab Dala'il khairat. Pengijazahan ini biasanya dilakukan langsung oleh Pendiri Pondok Pesantren Kyai Qusyairi Abshor. Pada saat pengijazahan, semua peserta yang telah memulai puasanya pada awal Muharram, diwajibkan untuk membawa kitab Dala'il Khairat. Proses ijazah dianggap sah apa bila seorang mu'jiz (yang mengijazahkan) mengatakan "Ajaztu" yang dalam Bahasa Indonesianya berarti saya ijazahkan, kemudian peserta menjawab "Qabiltu" yang artinya saya terima ijazahnya.

Selain kitab-kitab Dala'il khairat, dalam prosesi ijazah kubro ini ada juga wirid dan kitab lainnya yang diijazahkan antara lain Kitab Hikmatul Bariz, Kitab Ijazah Kubro, Kitab Qalbu Alquran, Hizib Maghrabi, Hizb Barqi, Hizib Jailani dan lainnya.

Setelah kegiatan pengijazahan, dilanjutkan dengan zikir dan doa yang dipimpin oleh Mu'jiz. Pada tahap ini biasanya peserta dan undangan meletakkan air, benda, ataupun lainnya untuk diberikan barakahnya. Dalam dunia pesantren kegiatan ini dikenal dengan istilah 
Selanjutnya, setelah semua rangkaian kegiatan selesai, peserta dan undangan pun kembali pulang. Acara ini biasanya berlangsung sampai datangnya waktu Shubuh. Sehingga Ketika shubuh datang, acara dilanjutkan dengan shubuh berjamaah serta menyantap sarapan pagi yang telah disuguhkan oleh pihak pesantren.

Event ini biasanya juga dimanfaatkan oleh para pedagang sekitar pondok untuk meraup rezeki pada kegiatan tersebut. Sehingga tidak heran pada acara tersebut dipenuhi oleh pedagangpedagang, mulai dari pedagang mainan, makanan, minuman sampai pedagang pakaian dan lainnya.

Dari Data santri yang didokumentasikan pihak pesantren setiap tahunnya, peneliti melihat ada kenaikan angka bagi yang mengikuti dan telah khatam dalam melakukan puasa tersebut. Dalam penelitian ini, peneliti hanya menyajikan data peserta yang mengikuti ijazah kubro terakhir yang diselenggarakan Pondok Pesantren Syafa'atu Thulab, yakni pada tanggal 28 Agustus 2020. Meski pada moment ijazah kali ini, Desa Bakung, dan Indonesia secara umum sedang mengalami musibah wabah Copid 19, namun kegiatan ijazah kubro ini tetap berjalan seperti biasa tentunya dengan mengikuti prosedur protocol yang telah ditentukan. Menurut keterangan yang disampaikan oleh Pimpinan Pondok Pesantren, bahwasanya ijazah kali merupakan ijazah terbanyak se-Indonesia, mengungguli jumlah di daerah jawa di mana tradisi puasa ini banyak dilakukan.

\section{Peran Pondok Pesantren Syafa'atut Thulab Melestarikan dan Mensyiarkan Tradisi Puasa Dala'il Khairat di Kabupaten Ogan Ilir}

Pondok Pesantren Syafa'atu Thulab sebagai lembaga keagamaan, memiliki peranan yang sangat penting dalam bidang pendidikan dan pengembangan karakter santri. Sebagai salah satu pesantren salaf yang notabennya menganut paham Ahlussunnah Wa al-Jama'ah, Pondok Pesantren Syafa'atu Thulab merupakan satu-satunya Pondok Pesantren di Kabupaten Ogan Ilir yang memasukkan tradisi Puasa Dala'il Khairat sebagai salah satu kurikulum pesantren. Kurikulum ini tentunya menjadi daya tarik sendiri bagi pengembangan dan keberlangsungan pesantren, ditengah makin maraknya pertumbuhan pesantren di lingkungan Kabupaten Ogan Ilir.

Semenjak awal berdirinya, Pondok Pesantren Syafa'atu Thulab telah menjadikan praktek puasa Dala'il khairat ini sebagai kurikulum informal pesantren, sehingga tidak heran setiap tahunnya para santri yang belajar dan mondok di sana, banyak yang ikut berpartisipasi mengamalkannya. Mulai dari tingkat Ibtidaiyah, Tsanawiyah dan 'Aliyah, bahkan ada juga beberapa wali santri yang ikut mengamalkannya.

Tercatat pada tahun 2020 ada 260 orang yang telah menyelesaikan khataman puasa ini. 
Jumlah ini merupakan jumlah terbesar se-Indonesia dan telah dimufakati oleh Pondok Pesantren se-Indonesia yang mengamalkan tradisi ini.

Upaya pesantren dalam melestarikan tradisi Puasa Dala'il Khairat, dapat dilihat pada program tahunan wajib yang diselenggarakan pada tujuh Syuro atau 7 muharram yakni kegiatan Ijazah Kubro. Kegiatan ini biasanya disosialisakan kepada seluruh santri dan masyarakat luas. Sehingga tak heran pada acara tersebut, banyak peserta yang hadir, bukan saja dari wali santri bahkan kerabat-kerabat santri serta masyarakat yang tahu tentang acara tersebut juga ikut hadir.

Terlebih lagi dalam kegiatan ijazah ini, bukan saja Dalalil Khairat saja yang diijazahkan namun banyak lagi lagi doa, wirid dan kitab-kitab lainnya yang diijazahkan dalam kegiatan tersebut. Bagi orang-orang yang mengerti tentang sanad untuk mengamal-kan sebuah wirid atau doa tentunya tertarik untuk mengikuti acara tersebut. Kegiatan tahunan Pondok Pesantren Syafa'atu Thulab ini, menambah daya pikat tersendiri, tidak hanya ekitar pesantren, namun juga di luar desa bahkan luar kabupaten dan luar provinsi.

Selain itu, sebagai mudir sekaligus pendiri pesantren Syafa'atu Th , _ _ syairi Abror juga mempunyai peran penting dalam melestarikan tradisi puasa Dala'il khairat ini, sikapnya yang selalu memberikan pemahaman terhadap masyarakat sekitar yang asing dengan tradisi tersebut, membuat kegiatan ini tidak mendapat penolakan dari pihak manapun. Beliau selalu terbuka manakala ada orang yang bertanya tentang puasa ini. Selanjutnya, kepribadian beliau juga menjadi faktor utama semakin banyaknya santri yang mondok dan turut mengamalkan puasa tersebut.

Pesantren juga menjalin relasi yang baik dengan pihak pemerintahan serta organisasi keagamaan baik di tingkat kabupaten, provinsi maupun nasional, sehingga tidak heran ketika malam pengijazahan tersebut para pejabat maupun pengurus organisasi keagamaan juga hadir pada kegiatan tersebut, dan dari mereka jugalah tersebarnya pondok pesantren ini dengan ciri khas puasanya.

\section{Kendala yang Dihadapi Pondok Pesantren Syafa'atut Thulab dalam Mensyiarkan Tradisi Puasa Dala'il Khairat}

Untuk menjalankan sesuatu yang baik, tentu akan ada banyak rintangan yang menjadi penghalang tercapai tujuan baik tersebut. Halangan dan rintangan tersebut bisa muncul dari diri sendiri maupun dari luar (orang lain). Tentunya setiap halangan harus dihadapi dengan bijak untuk mendapatkan hikmahnya.

Upaya pondok pesantren dalam mensyiarkan tradisi puasa ini, tentunya juga mendapat 
banyak kendala terlebih dari pengamalnya sendiri. Seperti yang diungkapkan oleh Kyai Qusyairi Abror sebagai berikut: ${ }^{11}$

"Pada awalnya memang banyak kendala, karena ryadhah ini memang tidak biasa. Apalagi untuk anak-anak yang masih duduk di sekolah Ibtidaiyah, ada saja halangan seperti penyakit maag, usia yang masih ingin bermain serta pengaruh kawan-kawan sekitarnya yang tidak ikut puasa, namun lambat laun kendala ini berangsur hilang meski masih ada beberapa termasuk bagi yang baru membiasakan. Seperti halnya kita menjalankan puasa Ramadhan, banyak sekali kendala ketika diawal, maag kambuh, godaaan dari kawan terdekat, perasaan haus dan lapar dan sebagainya, namun hal ini akan jadi terbiasa setelah dilakukan secara istiqamah dan dengan niat yang tulus karena Allah.

Senada dengan itu juga, peneliti juga mewawancarai langsung beberapa pengamal, diantaranya ${ }^{12}$

"Awalnya memang berat, dan ingin membatalkan karena tidak tahan haus dan lapar, pada hari pertama sampai ketujuh terasa godaannya begitu besar",

Dalam wawancara lain dengan pengamal bernama mengatakan ada juga yang sampai muntah-muntah pada hari pertama-tama puasa, karena godaannya lebih berat dibanding puasa bulan Ramadhan.

Sebenarnya yang menjadi kendala besar bagi Pondok Pesantren dalam melestarikan tradisi puasa ini hanya terletak pada pembiasaan awal saja, karena sebelumnya para santri yang mondok di pesantren tersebut umumnya sudah tahun tradisi yang dijalankan di pondok tersebut, dan salah satu motivasi besar besar mereka yang mondok adalah menjadi pengamal puasa tersebut.

Seiring dengan padatnya jadwal pengasuh pesantren untuk memenuhi undangan mengisi pengajian di berbagai pengajian di luar pesantren, hal ini juga berdampak dengan makin tersebarnya Pesantren Syafa'atu Thulab yang memiliki identitas sebagai salah satu pondok salafiyah yang masih menjalankan tradisi puasa, termasuk puasa dalalil khairat.

\section{Respon Masyarakat Terhadap Tradisi Puasa Dala'il Khairat}

Masyarakat Indonesia memiliki banyak tradisi dan budaya yang berasal dari kearifan lokal, yang dipengaruhi oleh ajaran agama, kebiasaan adat istiadat dan aturan nenek moyang. Dalam sejarahnya puasa Dala'il Khairat adalah jenis puasa yang berkembang di masyarakat daerah Kudus/Pati, Jawa Tengah, yang kemudian disebarkan oleh para murid-muridnya melalui sanad. Sanad inilah yang merupakan mata rantai pengamalan puasa hingga ke penulis Kitab Dala'il Khairat, yakni Syaikh Sulaiman al-Jazuli. Sanad ini diberikan kepada pengamal yang telah menyelesaikan puasa.

\footnotetext{
${ }^{11}$ M. Qusyairi Abror, “Pimpinan Pondok Pesantren Syafa'atu Thulab,” August 25, 2020.

12 "Santri Pondok Pesantren Syafa'atu Thulab Dhia Afriani," August 25, 2020.
} 
Keberadaan puasa Dala'il Khairat masih asing di kalangan umum atau masyarakat di Indonesia, puasa Dala'il Khairat hanya dikenal oleh kalangan pesantren dan oleh para ulama. Sementara itu, orang-orang di kalangan umum yang mendengar pelaksaan puasa Dala'il Khairat akan memiliki persepsi yang negatif, karena ibadah tersebut bersifat paksaan, bahkan banyak orang berpendapat, bahwa puasa ini adalah ajaran yang sesat karena tidak adanya referensi hadist nabi Muhammad SAW. Terlepas dari keasingan dan pendapat tersebut, tentunya bagi para pengamal mempunyai dalil yang berbeda, dan menjadikan praktek ini masih tetap lestari hingga saat ini.

Terkait hal ini, peneliti juga melakukan wawancara kepada beberapa responden mengenai tradisi puasa Dala'il Khairat yang diamalkan di Pondok Pesantren Syafa'atu Thulab Desa Bakung Kecamatan Inderalaya Utara Kabupaten Ogan Ilir. Dari beberapa responden yang berhasil diwawancarai, memang tidak semua memberikan respon yang positif, namun meskipun demikian tidak ada satupun yang menolak secara terang-terangan.

Seperti pengungkapan Safarudin ${ }^{13}$ seorang tokoh agama di Desa bakung, beliau mengatakan bahwa;

"Pada prinsipnya saya pribadi tidak menolak dengan adanya tradisi puasa yang ada di pondok pesantren Syafa'atu Thulab, karena setiap pengamal pasti telah memiliki berbagai dalil sebelum mengamalkannya, terlebih menurut ceritanya bahwa puasa ini juga banyak dilakukan di daerah Jawa. Kalau di daerah Jawa mungkin masyarakatnya tidak heran lagi, karena di Jawa sendiri banyak macam-macam puasa ini, seperti puasa mutih, tidak makan nasi, puasa ngerawot puasanya hanya makan ubi dan banyak lagi. Sedangkan penduduk kita memang masih asing dengan puasa-puasa seperti ini. Namun prinsip kita tidak pernah mengatakan itu salah, dan tidak pula membenarkannya.

Tambahnya lagi:

"Saya dan masyarakat di sini selalu hadir ketika diundang dalam hajatan Pondok Pesantren Syafa'atu Thulab, termasuk hajatan Ijazah bagi pengamal-pengamal puasa Dala'il khairat, antara pesantren dan masyarakat tidak pernah ada konflik apapun. Dan Ketika ada kegiatan di Masjid kita (maksudnya Desa Bakung di luar Pondok Pesantren Syafa'atu Thulab), kita juga mengundang kyai Pesantren serta santrinya, dan mereka hadir, kadang mengisi acara, kadang juga hadir sebagai undangn saja."

Hal yang senada juga diungkapkan oleh tokoh msyarakat bernama Hasan Gani (65 Tahun $)^{14}$, beliau mengungkapkan sebagai berikut:

"Kalo konflik dak katek, dak pernah ado, yo...setau aku puasa itu cuma puasa Ramadhan, dak tahu aku ado puaso-puaso lain, temasuk puaso yang diamalkan di Pondok Pesantren kami ni. yo cuman bagi kami yang dak tau ni, yo sebatas itulah, kami idak melok gawekannyo, ado sih ado beberapo yang melok gawekenyo, cuman memang idak banyak, paling dari wali santri yang mondok di sanolah, dan setiap acara ijazah itu kami diundang, dan melok hadir jugo menyaksikan. Amen kami yo meraso takjub

\footnotetext{
13 “Tokoh Agama Desa Bakung Safarudin,” August 26, 2020.

14 “Tokoh Masyarakat Desa Bakung Hasan Ghani," August 26, 2020.
} 
bae, ado yang pacak puaso sampe betaun-taun tiap ari."

Terjemah:

Kalau konflik tidak pernah ada, ya...setahu saya puasa itu hanya ada puasa Ramadhan, tidak tahu ada puasa-puasa lain termasuk puasa yang diamalkan di Pondok Pesantren kami ini. ya...hanya saja bagi kami yang awam ini, hanya sebatas itu saja, kami tidak ikut melakukannya, ada sih ada beberapa yang ikut mengamalkannya, hanya saja tidak banyak, di antara dari wali santri yang sekolah di sana, dan setiap acara ijazah kami diundang dan ikut hadir juga menyaksi-kan. Kalau kami ya..merasa takjub, ada yang bisa melakukam puasa sampai bertahun-tahun setiap hari.

Selain tokoh di atas, peneliti juga melakukan wawancara terhadap tokoh $\mathrm{NU}^{15}$ yang ada di Ogan Ilir, terkait praktek puasa yang ada di Pondok Pesantren Syafa'atu Thulab Desa Bakung sebagai berikut:

"Saya selaku warga NU menyambut baik dengan apa yang telah dilakukan oleh Kyai Qusyairi Abror dalam melestarikan tradisi puasa Dala'il khairat ini. Karena di Kabupaten Ogan Ilir sendiri dari sekian banyak Pondok Pesantren Salafiyah, hanya di Pesantren ini saja yang melakukan praktek puasa ini. Kami selalu diundang dalam kegiatan tersebut, dan saya selaku pengurus Nahdhatul Ulama di Kabupaten Ogan Ilir ini selalu hadir kalua tidak berhalangan. Prinsipnya, setiap orang punya cara sendiri untuk dekat dengan Tuhannya, ada yang dengan mendawamkan shalat Tahajjud setiap malam, atau Dhuha setiap pagi. Ada juga dengan selalu bersedekah setiap hari atau setiap jumat, dan ada juga yang berpuasa setiap hari seperti puasa yang dilakukan di pondok pesantren Syafa'atu Thulab ini. Setiap orang berbeda-beda jalannya untuk mendekatkan dirinya dengan Tuhannya."

Dari pendapat-pendapat di atas, serta riwayat konflik yang saya dapatkan dari hasil observasi dan wawancara, maka peniliti dapat menyimpulkan bahwa keberadaan tradisi yang dianggap asing bagi masyarakat luar pesantren ini tidak ditemukannya penolakan meskipun ada juga yang tidak sependapat dengan praktek tersebut, dan kegiatan ini masih dapat dipertahankan dan dilestarikan oleh Pondok Pesantren sebagai kurikulum informal yang menjadi pembeda dari pesantren-pesantren salafiyah lainnya yang ada di Kabupaten Ogan Ilir sejak berdirinya sampai sekarang.

\section{E. KESIMPULAN}

Pondok Pesantren Syafa'atu Thulab merupakan salah satu Pondok Pesantren salafiyah yang masih mempertahankan tradisi-tradisi kepesantrenan yang berbasis kitab kuning. Salah satu kitab yang fenomenal karena menjadi bacaan dan wirid bagi pengamal puasa dahr (puasa 
tahunan) yakni Kitab Dala'il Khairat karangan Syaikh Sulaiman al-Jazuli. Sehingga puasanya sendiri disebut puasa Dala'il Khairat.

Pelaksanaan Puasa Dala'il Khairat di Pondok Pesantren Syafa'atu Thulab sudah ada sejak Pondok Pesantren ini didirikan. Tradisi puasa ini merupakan bagian dari kurikulum informal yang menjadi identitas dari pesantren. Ada beberapa rangkaian kegiatan terkait pelaksanaan puasa Dala'il Khairat ini yang dirangkum dalam kegiatan besar tahunan bernama Ijazah Kubro. Kegaiatan ini biasanya diselenggarakan pada 7 Syuro atau tanggal 7 Muharram setiap tahunnya. Kegiatan inti dari ijazah kubro ini adalah Penyerahan Piagam bagi pengamal puasa yang telah khatam dan prosesi ijazah kitab Dala'il khairat.

Pengamal puasa Dala'il Khairat di lingkungan Pesantren Syafa'atu Thulab semakin meningkat dari tahun ke tahun, tercatat pada tahun 2020 jumlah pengamal puasa di Pesantren ini merupakan jumlah paling banyak se-Indonesia. Melihat banyak-nya pengamal puasa Dala'il Khairat baik dari kalangan santri dan non santri dari tahun ke tahun ini, menunjukkan adanya peran besar pesantren dalam melestarikan tradisi puasa ini, baik di lingkungan Pesantren maupun di luar Pesantren.

\section{DAFTAR PUSTAKA}

Abror, M. Qusyairi. “Pimpinana Pondok Pesantren Syafa'atu Thulab,” June 10, 2020.

—. "Pimpinana Pondok Pesantren Syafa'atu Thulab," August 25, 2020.

Arafat, Ahmad Tajuddin. "Tiga Ulama Pentashih Kitab Nailul Masarrat.” Pesantren.Id, July 2020. Accessed September 2, 2020. https://pesantren.id/tiga-ulama-pentashih-kitabnailul-masarrat-karya-kh-ahmad-basyir-kudus-5325/.

Kisbiyanto. Sejarah Pengarang Kitab Dalailul Khairat Syakh Abu Abdillah Muhammad Bin Sulaiman Al-Jazuli. PP Darul Falah Jekulo Kudus, 2000.

Masturin. "Perilaku Sosial Budaya Pengikut Tarekat Dalailul Khairat Pada Pondok Pesantren Darul Falah Jekulo Kudus.” Kuriositas: Media Komunikasi Sosial dan Keagamaan Vol. 8, No. 1 (2015). http://ejurnal.stainparepare.ac.id/index.php/kuriositas/article/view/141.

ar-Rahman, Abd. Taisir Al-Karim Ar-Rahman Fi Tafsir Kalam al-Mannan,Muassasah ArRisalah, Riyadh, n.d.

Rohman, Muhammad Mujibur, and Dewi Liesnoor Setyowati. "Pendidikan Karakter Di 
Tamaddun: Jurnal Kebudayaan dan Sastra Islam, Vol. 20 No. 2, 2020 |

Pesantren Darul Falah Kecamatan Jekulo Kabupaten Kudus." Journal of Education Social Studies Vol. 1, No. 2 (2012).

“Kamus Besar Bahasa Indonesia,” n.d. Accessed July 20, 2020. https://kbbi.web.id/ijazah.

“Santri Pengamal Puasa Dalail Khairat,” June 11, 2020.

“Santri Pondok Pesantren Syafa'atu Thulab Dhia Afriani,” August 25, 2020.

“Tokoh Agama Desa Bakung Safarudin,” August 26, 2020.

“Tokoh Masyarakat Desa Bakung Hasan Ghani,” August 26, 2020.

“Tokoh NU Kab. Ogan Ilir Ahmad Nahrowi,” August 26, 2020. 